УДК 336.71

DOI: https://doi.org/10.37320/2415-3583/12.34

Рудевська B.I.

кандидат економічних наук, доцент, ДВНЗ «Університет банківської справи» ORCID: https://orcid.org/0000-0001-6697-9096

\title{
ТЕОРЕТИЧНІ ПІДХОДИ ДО ВИЗНАЧЕННЯ СУТНОСТІ БАНКІВСЬКОї ДІЯЛЬНОСТІ
}

У статті досліджено наукові підходи до визначення сутності банківсь-кої діяльності. У процесі аналізу виявлено, ще в науковому середовищі є плюралізм у трактуванні сутності банківської діяльності, проте є можливість їх згрупувати за концептуальними підходами до визначення змісту банківської діяльності. У статті розглянуто історичний розвиток банківської діяльності, щуо свідчить про позитивну динаміку зростання ролі банків в економіці. Важливо, щзоб банківський сектор економіки розвивався синхронно з національним господарством. 3 часом класична банківська діяльність доповнилася новими видами банківських операчій та банківських послуг, щзо свідчить про початок процесу трансформаиії банківського бізнесу. Діяльність банків набуває нових рис у класичних операціях та розширює сферу послуг у контексті технологічного прогресу, щзо не змінює сутності банківської діяльності. У дослідженні обірунтовано власне трактування банківської діяльності, яке дає можливість врахувати функиіональні особливості банківської діяльності, наявність яких дає змогу ї̈ чітко ідентифікувати та підкреслити соціальний та економічний ефекти від неї.

Ключові слова: банк, комериійний банк, банківська діяльність, фінансові посередники, специфічні риси банківської діяльності.

Постановка проблеми. Банківський сектор сьогодні займає вагоме місце у структурі національної та світової економіки. В умовах глобалізації уявити роз- виток національного господарства без банківського сегменту неможливо. Одночасно зростають і ризики важливості банків та стійкості банківської системи. 
Динамічність економічних процесів в країні та світі, а також розвиток нових технологій зумовлюють зміни у роботі банківських установ. Банки, з інституціональної та соціально-економічної позицій, стали потужними інструментами впливу на бюджетну, податкову, грошову системи.

Очевидно, що визначення банківської діяльності в законодавстві та наукових працях не зовсім відповідає вимогам часу та місцю банків у системі економічного зростання країни. У підходах до трактування банківської діяльності є різні думки, проте жодне не враховує сучасного визначення банківської діяльності, яке повинно базуватися на комплексному підході, що розширює і доповнює вже наявні.

Аналіз останніх досліджень і публікацій. Поставленій проблемі в науковій літературі присвячено чимало вітчизняних та зарубіжних праць сучасних науковців. Вітчизняні вчені С.В. Буряк, В.В. Дружиніна, Т.С. Смовженко, В.І. Ричаківська, П.М. Сенищ, В.А. Шпильовий, В.І. Міщенко, А.Я. Кузнєцова та інші досліджували питання сутності банківської діяльності. Іноземні вчені Дж. Сінкі, П. Роуз, Е. Долан, П. Самуельсон, К.Т. Трофимов також внесли вагомий доробок у питання визначення змісту банківської діяльності. Більш детальний аналіз досліджень із поставленої проблематики викладено в основній частині статті.

Мета статті полягає в аналізі наявних наукових підходів до визначення сутності та змісту поняття «банківська діяльність» та обгрунтуванні власного трактування банківської діяльності, що базується на комплексному підході.

Виклад основного матеріалу. Зростання економіки залежить у тому числі і від акумуляції та розпо- ділу грошових ресурсів, які в основному здійснюються банками. Розвиток банківської діяльності зумовлений потребами клієнтів у банківських операціях та зростанням конкуренції у грошово-кредитній сфері. Банківська діяльність сприяє руху грошових ресурсів, виконанню боргових зобов'язань, стимулюванню інвестиційних процесів. В умовах цифровізації економіки та розвитку технологій фінансового бізнесу перед банками виникає проблема пошуку шляхів підвищення ефективності банківської діяльності та нових підходів до створення конкурентних переваг.

Історичний підхід у дослідженні банківської діяльності свідчить, що перші різновиди операцій обміну грошей здійснювались у Стародавньому Вавилоні, Стародавній Греції, Стародавньому Сгипті, Стародавньому Римі. Так, на півночі Італії на площах встановлювали лави для обміну монет. Пізніше в Свропі появилися перші лихварі, які співпрацювали 3 торговими та королівськими дворами. Розповсюджувачами банківництва також стали комерсанти та торгові банкіри, які укладали угоди обміну. У період існування мануфактур появилися «банківські будинки», які кредитували промисловців та торговців.

Отже, історичний розвиток банківської діяльності свідчить, що банки з часів античності почали відігравати ключову роль у фінансово-кредитному механізмі держави та житті суспільства. Сьогодні дослідження банківської діяльності на макро- та мікрорівнях становить значний науковий інтерес.

Виділяють чотири основних етапи розвитку банківської діяльності (рис. 1).

Етапи розвитку банківської діяльності свідчать про позитивну динаміку зростання ролі банків в еконо-

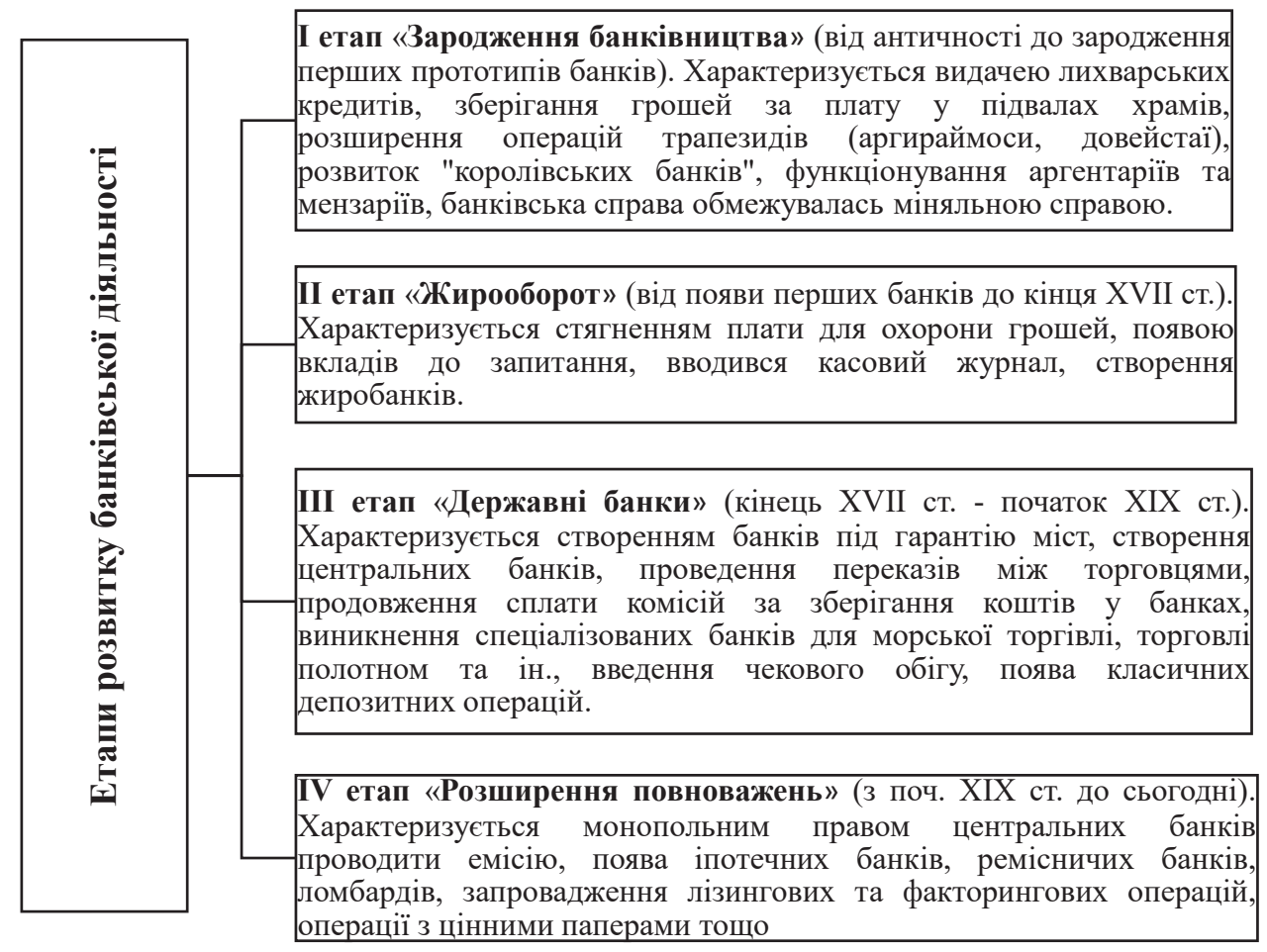

Рисунок 1 - Етапи розвитку банківської діяльності 
міці. Вони акумулюють та розподіляють значні фінансові ресурси фізичних та юридичних осіб, що сприяе створенню додаткової вартості в структурі валового внутрішнього продукту. 3 іншого боку, банки здійснюють розрахунково-касове обслуговування економічних контрагентів та відіграють значну роль у подоланні економічних криз.

Суть основної банківської діяльності полягає в «діяльності кредитної організації, яка включає банківські операції та угоди», а допоміжної - в «діяльності, що спрямована на забезпечення сприятливих і безпечних умов здійснення основної банківської діяльності, наприклад охорона, система безпеки та інші аналогічні види діяльності спеціальних підрозділів кредитної організації» [2, с. 25-26].

Зрозуміло, що сьогодні значно збільшився перелік операцій та вплив банків на економічні процеси, що значно збільшило ризики стабільності фінансових систем країн. Окремі фахівці виділяють вже «необанки» як банки майбутнього. Необанк - це «компанія, яка забезпечує банківський та платіжний сервіс без традиційної інфраструктури банківських відділень» [3]. Тобто по суті це - онлайн-банки, які будуються 3 «нуля» на технологічних платформах. Такий розвиток подій стимулює до пошуку нових чи вдосконалення наявних підходів до банківської справи. Наприклад, юридичний та інституційний підходи потребують значного вдосконалення у питаннях процедури та державного регулювання.

Варто зазначити, що окремі вчені ототожнюють поняття «банківська діяльність» та «банківські операції» [4, с. 29]. Такий підхід не відображає банківську діяльність повною мірою та звужує це поняття. Насправді банківська діяльність не може обмежуватися переліком банківських операцій, бо включає в себе правову, публічну та підприємницьку діяльність.

Розглянемо тлумачення поняття «банківська діяльність» у науковій лі-тературі більш детально (табл. 1).

Вчені по-різному тлумачать поняття «банківська діяльність». Так, одні розглядають банківську діяльність в аспекті процесів, у яких залучено банки, а інші - ототожнюють іiі з посередницькими операціями

Таблиця 1 - Сутність поняття «банківська діяльність»

\begin{tabular}{|c|c|c|}
\hline № & Визначення & Автор, джерело \\
\hline 1 & $\begin{array}{l}\text { Банківська діяльність - це сукупність дій, які мають певну спрямованість та дають змогу } \\
\text { на «виході» забезпечувати якість виконання банківських операцій та надання послуг банку }\end{array}$ & $\begin{array}{l}\text { Шпильовий В.А. } \\
{[5, \text { с. } 18]}\end{array}$ \\
\hline 2 & $\begin{array}{l}\text { Банківська діяльність - це сукупність діючих спеціальних суб'єктів і операцій, які } \\
\text { здійснюються банками згідно } 3 \text { переліком, встановленим законом, як учасниками єдиної } \\
\text { банківської системи } 3 \text { приводу грошей, цінних паперів та валютних цінностей як засобів } \\
\text { платежу, заощадження й товару. }\end{array}$ & $\begin{array}{l}\text { Дружиніна В.В., } \\
\text { Буряк Є.В., } \\
\text { Нестеренко А.О. } \\
{[6, \text { с. } 164]}\end{array}$ \\
\hline 3 & $\begin{array}{l}\text { Банківська діяльність (із правової позиції) - це сукупність правових дій, що здійснюються } \\
\text { певними суб’єктами у формі, встановленій законом або договором. Основними } \\
\text { характеристиками є мета, суб’єкти (банки) й об'єкти (контрагенти). Ї̈і реалізація значною } \\
\text { мірою залежить від волевиявлення контрагентів, однак їхні дії є середовищем, в якому } \\
\text { основним суб’єктом завжди виступає банк як спеціалізована установа. }\end{array}$ & $\begin{array}{l}\text { Коваленко В.В., } \\
\text { Коренєва О.Г., } \\
\text { Черкашина К.Ф., } \\
\text { Крухмаль О.В. } \\
\quad[1, \text { с. } 151]\end{array}$ \\
\hline 4 & $\begin{array}{l}\text { Банківська діяльність - це публічно-правова діяльність у межах законодавства, яка } \\
\text { реалізовується центральним банком із метою стабільності національної одиниці, } \\
\text { характеризується розвитком та зміцненням банківської системи, розвитком національної } \\
\text { платіжної системи, розвитком та забезпеченням стабільності фінансового ринку країн, а } \\
\text { також є різновидом підприємницької діяльності, що здійснюється кредитними установами, } \\
\text { зареєстрованими відповідно до законодавства, які проявляються у здійсненні банківських } \\
\text { операцій та інших угод із метою отримання прибутку. }\end{array}$ & $\begin{array}{l}\text { Кузнецова Н.О. } \\
{[7, \text { с. } 471-472]}\end{array}$ \\
\hline 5 & $\begin{array}{l}\text { Банківська діяльність - підприємницька діяльність кредитних організацій та діяльність } \\
\text { центрального банку, спрямована на системне здійснення банківських операцій на основі } \\
\text { законодавства та ліцензії. }\end{array}$ & $\begin{array}{c}\text { Яковлєв I.В. } \\
{[8, \text { с. } 78]}\end{array}$ \\
\hline 6 & $\begin{array}{l}\text { Банківська діяльність - це підприємницька діяльність кредитних організацій на ринку } \\
\text { фінансових послуг із виконання функцій посередника для надання кредитів, здійснення } \\
\text { платежів і руху капіталу, що базується на законодавстві та ліцензії. }\end{array}$ & $\begin{array}{c}\text { Трофимов К.Т. } \\
{[9, \text { с. } 94]}\end{array}$ \\
\hline 7 & $\begin{array}{l}\text { Банківська діяльність грунтується на терміні «tone at the top», що використовується для } \\
\text { опису загального етичного клімату організації, встановленого іiі акціонерами, вищим } \\
\text { керівництвом, підрозділом аудиту, який включає те, що запобігти шахрайству, надмірній } \\
\text { ризиковості, неетичним діям може тільки вище керівництво та акціонери. }\end{array}$ & $\begin{array}{l}\text { Дрозд І.В. } \\
{[10, \text { с. } 117]}\end{array}$ \\
\hline 8 & $\begin{array}{l}\text { Банківська діяльність - це робота банку як динамічної відкритої системи, яка зумовлена } \\
\text { його функціями в економіці та характеризується відповідним результатом на макро- і } \\
\text { на мікрорівнях; процес акумулювання фінансових ресурсів та ї розміщення; процес } \\
\text { максимізації доходів акціонерів з метою управління ефективністю банківського бізнесу. }\end{array}$ & $\begin{array}{c}\text { Буряк А.В. } \\
{[11]}\end{array}$ \\
\hline 9 & $\begin{array}{l}\text { Банківську діяльність визначає складний комплексний характер відносин у сфері банківництва, } \\
\text { який включає операції залучення депозитів, надання кредитів, здійснення розрахунків, що } \\
\text { становлять iї первинну сферу, } 3 \text { метою комплексного, якісного обслуговування клієнтів, } \\
\text { задоволення потреб суспільства у банківських послугах та продуктах. }\end{array}$ & $\begin{array}{l}\text { Кльоба Л.Г., } \\
\text { Кльоба В.Л., } \\
\text { Кльоба Р.Л. } \\
{[12, \text { с. } 58]}\end{array}$ \\
\hline 10 & $\begin{array}{l}\text { Банківська діяльність - це виробництво або створення банківського продукту, прямий } \\
\text { чи опосередкований прибуток банку від реалізації якого дає змогу диференціювати ії на: } \\
\text { депозитну, кредитну, інвестиційну і розрахунково-платіжну. }\end{array}$ & $\begin{array}{c}\text { Сенищ П.М. } \\
\text { [13] }\end{array}$ \\
\hline
\end{tabular}

Джерело: сформовано автором на основі [1; 5-13] 
тощо. Очевидно, що визначення банківської діяльності в наукових працях не зовсім відповідає вимогам часу та місцю банків у забезпеченні економічного зростання країни.

Динамічність економічних процесів у країні та світі, а також розвиток нових технологій зумовлюють зміни у роботі банківських установ. Діяльність банків набуває нових рис у класичних операціях та розширює сферу послуг у контексті технологічного прогресу. 3 часом класична банківська діяльність доповнилася новими видами банківських операцій та банківських послуг, а поняття «банк» стали підміняти поняттям «фінансовий інститут», що свідчить про початок процесу трансформації банківського бізнесу [14, с. 86]. Економічною основою банківської діяльності з акумуляції та розміщення тимчасово вільних коштів $\epsilon$ рух грошових ресурсів, який є об'єктивним процесом впливу на формування та використання позиченої вартості. У такому контексті банк виступає комерційним підприємством, яке вигідно розміщує акумульовані кошти. Такий особливий статус банків можна пов'язати 3 їхньою відповідальністю за економічний розвиток через систему впливу на масу грошей в обігу. У такому разі й потрібна банківська система як система регулювання та нагляду за банківською діяльністю.

У науковій економічній літературі під час дослідження банківської діяльності основний акцент робиться на сутності банку та банківських операцій. На цій основі А.В. Буряк виділяе чотири основні концептуальні підходи до сутності банківської діяльності (табл. 2).

На нашу думку, перелік запропонованих підходів у табл. $1.2 є$ не вичерпним. По-перше, запропоновані підходи мають різну спрямованість, а по-друге - різні рівні дослідження змісту банківської діяльності. Так, функціональний підхід зосереджується на фінансовому результаті банків, а портфельний - на проблемах управління у банку. Тому сучасне визначення сутності банківської діяльності повинно базуватися на системно-комплексному підході, який передбачає розширення та доповнення попередньо запропонованих підходів. Ми пропонуємо розширити визначення сутності поняття «банківська діяльність», взявши за основу комплекс операцій, виконання яких дає можливість стверджувати, що фірма займається банківською діяльністю, та пропонуємо доповнити визначення соціальним навантаженням такої діяльності.

Таким чином, базуючись на комплексному підході, банківську діяльність можна визначити як фінансовоекономічну діяльність, яка включає в себе комплекс операцій із ведення рахунків, переказу коштів та залучення коштів для надання грошових кредитів із метою отримання прибутку, задоволення потреб суспільства в отриманні банківських послуг та забезпечення стабільності банківської системи. Таке визначення банківської діяльності дає можливість врахувати функціональні особливості банківської діяльності, наявність яких дає змогу іiі чітко ідентифікувати та підкреслити соціальний та економічний ефекти від неї.

Функції ведення рахунків та переказу коштів притаманні не тільки банкам, їх на ринку руху грошових коштів можуть також виконувати поштові агенти, платіжні системи і навіть деякі соціальні мережі. Проте вони функціонально не спроможні надавати грошові кредити, що не дає нам можливості стверджувати що вони здійснюють «банківську діяльність». Провайдери стільникового зв'язку відкривають рахунки, переказують грошові кошти між ними, але не можуть надавати грошових кредитів. Інші учасники фінансового ринку, які функціонально надають грошові кредити, такі як ломбарди, кредитні спілки та фінансові компанії, не можуть робити грошові перекази та формувати пасивну базу за рахунок депозитів. Таким чином, тільки одночасне виконання визначених у запропонованому трактуванні класичних функцій фірмою дає можливість стверджувати, що вона здійснює банківську діяльність, і обгрунтовує адекватність такого ії визначення.

Одночасно не можна відокремлювати від змісту банківської діяльності їі ринкові, економічні та соціальні цілі. У ринкових умовах будь-яка установа, що здійснює підприємницьку діяльність, має на меті отримання прибутку, що гарантує іiі функціонування, $\epsilon$ джерелом збагачення для власників. При цьому банківська діяльність має задовольняти потреби споживачів у банківських сервісах незалежно від форми та рівня дистанційності їх надання. Проте, на відміну від більшості бізнесів, банки несуть підвищений рівень відповідальності перед суспільством через свою здат-

Таблиця 2 - Концептуальні підходи до визначення змісту банківської діяльності

\begin{tabular}{|c|c|c|}
\hline Підходи & Характеристика & Представники \\
\hline Функціональний & $\begin{array}{l}\text { банківська діяльність визначається переліком функцій банківських } \\
\text { установ у національному господарстві та банківськими послугами }\end{array}$ & $\begin{array}{l}\text { П. Роуз, Е. Долан, } \\
\text { П. Самуельсон, А. Мороз, } \\
\text { В. Ричаківська, Т. Косова, } \\
\text { Р. Коповська }\end{array}$ \\
\hline Портфельний & $\begin{array}{l}\text { банківська діяльність досліджується як процес управління грошовими } \\
\text { потоками в процесі розміщення та залучення банківських ресурсів }\end{array}$ & $\begin{array}{l}\text { О. Васюренко, Г. Азаренкова, } \\
\text { Дж. Сінкі, Кейн, Сілі, } \\
\text { В. Балтенспенгер } \\
\end{array}$ \\
\hline Виробничий & $\begin{array}{l}\text { банківська діяльність визначається як виробничий процес, який } \\
\text { трансформує банківські ресурси і дохідні активи. За такого підходу } \\
\text { актуальною є теорія фірми }\end{array}$ & $\begin{array}{c}\text { М. Клейн, М. Монті, } \\
\text { Н. Мерфі, Ф. Бел., О. Карачун, } \\
\text { Дж. Сінкі, П. Конюховський }\end{array}$ \\
\hline Посередни & $\begin{array}{l}\text { банківська діяльність досліджується з інституційної позиції на мікро- } \\
\text { та макрорівнях. Основною метою банківської діяльності на мікрорівні } \\
\text { є отримання прибутку за рахунок економії, а на макрорівні -управління } \\
\text { ризиками, подолання асиметричності інформації та зменшення } \\
\text { трансакційних витрат }\end{array}$ & $\begin{array}{c}\text { Дж. Бенстона, Д. Даймонд, } \\
\text { Ф. Аллен, Д. Гейл, } \\
\text { К. ван К. Сміт }\end{array}$ \\
\hline
\end{tabular}

Джерело: сформовано автором на основі [11] 
ність впливати на стабільність банківської системи та економіки загалом.

Висновки. Визначення банківської діяльності не може обмежуватися тільки переліком банківських операцій, бо включає в себе правову, публічну та підприємницьку діяльність. Діяльність банків набуває нових рис у класичних операціях та розширює сферу послуг у контексті технологічного прогресу. Економічною основою банківської діяльності з акумуляції та розміщення тимчасово вільних коштів $\epsilon$ рух грошових ресурсів, який є об'єктивним процесом впливу на формування та використання позиче- ної вартості. 3 часом класична банківська діяльність доповнюється новими видами банківських операцій та банківських послуг.

Розгляд трактувань поняття «банківська діяльність» та підходів до визначення іiі змісту дав змогу запропонувати визначення банківської діяльності як фінансово-економічної діяльності, яка включає в себе комплекс операцій із ведення рахунків, переказу коштів та залучення коштів для надання грошових кредитів із метою отримання прибутку, задоволення потреб суспільства в отриманні банківських послуг та забезпечення стабільності банківської системи.

\section{Список використаних джерел:}

1. Банківська система України: монографія / В.В Коваленко., О.Г. Коренєва, К.Ф. Черкашина, О.В. Крухмаль. - Суми: ДВНЗ «УАБС НБУ», 2010. 187с.

2. Братко А. Г. Банковское право (теория и практика). Учеб. пособ. - М.: Пріор, 2000. - 320 с.

3. Необанки: закордонна історія та українська перспектива. Юридична Газета online. URL: https://yur-gazeta.com/ publications/practice/inshe/neobanki-zakordonna-istoriya-ta-ukrayinska-perspektiva.html.

4. Єгоричева С.Б. Організація діяльності банків у зарубіжних країнах: Навч. посібник. - К.: Центр учбової літератури, $2007-208$ c.

5. Шпильовий В.А., Фімяр С.В. Концептуальні підходи до визначення сутності банківської діяльності в умовах модернізації економічної системи. Агросвіт. 2015. № 13. С. 14-18.

6. Дружиніна В.В., Буряк Є.В., Нестеренко А.О. Теоретичні аспекти розвитку банківської діяльності. Вісник Хмельницького національного університету. 2011. № 2 (Т.1). С. 162-164.

7. Кузнецова Н. О. Понятие и сущность банковской деятельности. Молодой ученый. 2019. № 23. С. 470-472.

8. Яковлев И.В. Правовой анализ понятия «банковская деятельность». Сборник научных трудов кафедры уголовноправовых дисциплин Юридического института МГПУ. М., 2016. С. 74-96.

9. Трофимов К.Т. Проблемы правоспособности банка. Хозяйство и право. 2005. № 4. С. 89-95.

10. Дрозд І.В. Організаційно-функціональна трансформація банківського сектору економіки України: дис. канд. екон. наук : 08.00.08 / ДВНЗ «УБС». Київ, 2019. 312 с.

11. Буряк А.В. Теоретичні підходи до визначення змісту банківської діяльності. Ефективна економіка. 2011. № 10.

12. Кльоба Л.Г., Кльоба В.Л., Кльоба Р.Л. Методологічні підходи до визначення сутності банків та банківської діяльності. Економіка та держава. 2013. № 10. С. 55-58.

13. Сенищ П.М. Банківська діяльність в реалізації державної політики економічного зростання України. автореф. дис. на здобуття наук. ступеня д-ра екон. наук : 08.00.08. Київ, 2017. 42 с.

14. Мезенцева Л. А. Трансформация банковского бизнеса. Ученые записки Международного банковского института. 2016. № 15. C. 86-97.

\section{References:}

1. Kovalenko, V.V., \&Korenieva, O.H., Cherkashyna, K.F., Krukhmal', O.V. (2010) Bankivs'ka systema Ukrainy: monohrafiia [Ukrainain banking system] - Sumy: DVNZ UABS NBU [in Ukrainian].

2. Bratko, A. H. (2000) Bankovskoe pravo (teoryia y praktyka)[ Banking law (theory and practice)]. Ucheb. posob. - M.: Prior [in Russian].

3. Yurydychna Hazeta online: Neobanky: zakordonna istoriia ta ukrains'ka perspektyva. [Legal online newspaper Neobanks: foreign history and Ukrainian perspective] Retrieved from https://yur-gazeta.com/publications/practice/inshe/neobanki-zakordonnaistoriya-ta-ukrayinska-perspektiva.html. [in Ukrainian].

4. Iehorycheva, S.B. (2007) Orhanizatsiia diial'nosti bankiv u zarubizhnykh krainakh [Organization of banks' activities in foreign countries] - K.: Tsentr uchbovoi literatury [in Ukrainian].

5. Shpyl'ovyj. V.A., \&Fimiar. S.V. (2015) Kontseptual'ni pidkhody do vyznachennia sutnosti bankivs'koi diial'nosti v umovakh modernizatsii ekonomichnoi systemy [Conceptual approaches to defining the essence of banking in the modernization of the economic system] Ahrosvit-agroworld, 13, 14-18 [in Ukrainian].

6. Druzhynina, V.V., \&Buriak, Ye.V., Nesterenko, A.O. (2011) Teoretychni aspekty rozvytku bankivs'koi diial'nost [Theoretical aspects of banking development]. Visnyk Khmel'nyts'koho natsional'noho universytetu- Bulletin of Khmelnytsky National University, 2 \#1, 162-164 [in Ukrainian].

7. Kuznetsova, N.O. (2019) Poniatye y suschnost' bankovskoj deiatel'nosty [The concept of modern banking]. Molodoj uchenyjYoung scientist, 23, 470-472 [in Russian].

8. Yakovlev, Y.V. (2016) Pravovoj analyz poniatyia «bankovskaia deiatel'nost'» [Legal analysis of the concept of "banking"]. Sbornyk nauchnykh trudov kafedry uholovno-pravovykh dystsyplyn Yurydycheskoho ynstytuta MHPU-Collection of scientific works of the department of criminal law disciplines of the Law Institute of MSPU. (pp. 74-96). Moscow [in Russian].

9. Trofimov, K. T. (2005). Problemy pravosposobnosti banka [Problems of legal capacity of the bank]. Khoziaistvo i pravo Economy and law, 4, pp.89-95 [in Russian].

10. Drozd, I.V. (2019) Orhanizatsijno-funktsional'na transformatsiia bankivs'koho sektoru ekonomiky Ukrainy [Organizational and functional transformation of the banking sector of the Ukrainian economy]. Candidate's thesis. Kyiv: Banking University [in Ukrainian].

11. Buriak, A. V. (2011). Teoretychni pidkhody do vyznachennia zmistu bankivskoi diialnosti [Theoretical approaches to the definition of the content of banking activities]. Elektronne naukove fakhove vydannia «Efektyvna ekonomika» - Electronic scientific special edition «Effective economy», 10. Retrieved from http://www.economy.nayka.com.ua/?op=1\&z=727 [in Ukrainian]. 
12. Kl'oba, L.H.,\& Kl'oba, V.L., Kl'oba, R.L. (2013) Metodolohichni pidkhody do vyznachennia sutnosti bankiv ta bankivs'koi diial'nosti [Methodological approaches to defining the essence of banks and banking] Ekonomika ta derzhava - Economy and state, 10, 55-58 [in Ukrainian].

13. Senyshch, P. M. (2013). Bankivska diialnist u rozshyrenomu vidtvorenni ekonomiky: teoretychni aspekty [Banking activity in the extended reproduction of the economy: theoretical aspects]. Biznes Inform - Business Inform, 7, 277-282 [in Ukrainian].

14. Mezentseva, L. A., (2016). Transformatsyia bankovskoho byznesa [Transformation of the banking business] Uchenye zapysky Mezhdunarodnoho bankovskoho ynstytuta - Scientific notes of the International Banking Institute, 15, 86-9795 [in Russian].

\author{
Rudevska Viktoriia \\ University of Banking State Higher Educational Institution
}

\title{
THEORETICAL APPROACHES TO DETERMINING THE ESSENCE OF BANKING
}

Today, the banking sector occupies an important place in the structure of the na-tional and world economy. In the context of globalization, it is impossible to imagine the development of the national economy without the banking segment. At the same time, the risks to the stability of the banking system are growing. Obviously, the definition of banking in legislation and research does not quite meet the requirements of the time and the place of banks in the system of economic growth. There are different opinions in the approaches to the classification of banking activity, but no definition takes into account the modern definition of banking activity, which should be based on a comprehensive approach that expands and complements existing ones. The purpose of the article is to analyze the existing scientific approaches to defining the essence and content of the concept of "banking" and substantiate their own interpretation of "banking" based on an integrated approach. The research is focused on scientific approaches to defining the essence of banking. The analysis revealed that in the scientific community there is pluralism in the interpretation of the essence of banking. The article considers the historical development of banking, which indicates the positive dynamics of the growing role of banks in the economy. It is important that the banking sector of the economy develops synchronously with the national economy. It is important that the banking sector of the economy develops synchronously with the national economy. Over time, the classic banking activity was supplemented by new types of banking operations and banking services, which indicates the beginning of the process of transformation of the banking business. The activity of banks acquires new features in classical operations and expands the scope of services in the context of technological progress that does not change the essence of banking. The study substantiates the own interpretation of banking, which makes it possible to take into account the functional features of banking, the presence of which allows it to clearly identify and emphasize the social and economic effects of it.

Key words: bank, commercial banks, Financial Intermediaries, banking, banking system, specific features of banking.

JEL classification: G21, G28 